Warszawa 2019

PFLIT, no. 9(12), pt. 2: 55-68

GRAŻYNA BOBILEWICZ

Instytut Slawistyki Polskiej Akademii Nauk, Warszawa

\title{
ALTERNATYWNE BIBLIOTEKI \\ W PRZESTRZENI PUBLICZNEJ WSPÓŁCZESNYCH MIAST ŚWIATA (OD NATURY DO KULTURY)
}

Słowa kluczowe: alternatywne biblioteki, przestrzeń publiczna, miasta świata, XXI wiek Keywords: alternative libraries, public space, cities of the world, $21^{\text {st }}$ century

\section{ALTERNATIVE LIBRARIES IN THE PUBLIC SPACE OF MODERN WORLD CITIES (FROM NATURE TO CULTURE)}

\section{Su m m a ry}

Around the world, creative exponents of various disciplines (artists, architects, designers), social activists and members of local communities have challenged stereotypes in thinking and acting, by proposing and implementing experimental ideas of alternative libraries in place of traditional ones closed inside a building or contemporary, open and modernised libraries. In their concepts and artistic executions (installations, actions), they have referred to various traditions of public art. Untypical locations of the libraries within natural scenery, on beaches, in parks, etc. and in public and social spaces of modern cities have redefined the notion of a library, changed its form and content, and given it a new meaning and function. Alternative libraries have specific i.e. artistic, educational, social, ecological or intervention programmes, their main idea being the openness to new experiences and to people. They also follow certain rules: they operate by action and interaction, based on the process of interchange, they are self-service, free-of-charge libraries. Shelves of books, freed from the walls of buildings, or various artistic small architecture projects which serve the idea of borrowing and reading books in publicly accessible places, have transformed those places into intellectually inspiring areas. Selected alternative library models have been analysed with regard to the following interpretive factors: A library in natural space, Libraries on beaches, An open public library as an example of radical democracy, A library as 'a sculpture of knowledge', Street libraries (the idea and practice of bookcrossing, small free libraries), A library as an object of modern art.

\section{Wprowadzenie}

$\mathrm{Na}$ całym świecie toczą się dyskusje na temat aktualnej idei biblioteki. Przedstawiciele różnych dziedzin i dyscyplin badawczych (socjologii, antropologii, kulturoznawstwa, bibliotekoznawstwa, bibliologii, estetyki, animacji i edukacji 
kultury, semiotyki kultury, filozofii, psychologii, pedagogiki itd.) stawiają pytania, jakie funkcje powinna pełnić biblioteka jako instytucja kultury, jakie formy działalności prowadzić, w jaki sposób przekształcić swoją zewnętrzną i wewnętrzną przestrzeń, żeby zachęcić czytelników do efektywnego korzystania z jej zbiorów. Tradycyjny model biblioteki zamkniętej w ścianach budynku (o klasycznym wyglądzie, z trójpodziałem na przestrzeń dla czytelników, bibliotekarzy i zbiorów), która pełni nadrzędną rolę wobec jej użytkowników, ogranicza się do wyznaczonych zadań i funkcji (stan, historia, ochrona, dostępność zbiorów, transfer informacji) jest obecnie poddawana redefinicji i krytyce. Proponuje się nowy model „otwartej biblioteki”, który tworzą: nowoczesna architektura ${ }^{1}$, przyjazne fizyczno-duchowe otoczenie ${ }^{2}$, idea biblioteki jako „trzeciego miejsca” - przestrzeni, w której spędza się wolny czas wspólnie z innymi ${ }^{3}$, dostęp do wszystkich zbiorów i najnowszych systemów informacyjnych ${ }^{4}$, bibliotekarz jako animator kultury $^{5}$, dialog z czytelnikami. W myśl fenomenologicznej zasady, iż horyzonty poznania powinny być zawsze otwarte, współczesna biblioteka ma rozwijać zdolności do twórczego myślenia i kreatywnego działania.

W opozycji do tradycyjnego, uznanego modelu biblioteki zinstytucjonalizowanej (także tej unowocześnionej) powstaje oparty na koncepcji kreatywności zbiór przedstawień jeszcze bardziej otwartego modelu biblioteki, która, parafrazując refleksję Maurice'a Merleau-Ponty'ego z Fenomenologii percepcji,

${ }^{1}$ Lidia Szczygłowska, „Architektura bibliotek”, in Fizyczna przestrzeń biblioteki, ed. Maja Wojciechowska (Gdańsk: Oficyna Wydawnicza Edward Mitek, 2013), 22-39; Ольга Дубинина, Библиотека в пространстве современного города: Архитектура и дизайн. От прочлого к будущему (Москва: Библиомир, 2014).

${ }^{2}$ Tomasz Kruszewski, Przestrzenie biblioteki. O symbolicznej, fizycznej i społecznej obecności instytucji (Toruń: Wydawnictwo Naukowe Uniwersytetu Mikołaja Kopernika, 2012); Слава Матлина, Библиотечное пространство: воображаемый образ и реальность (Москва: Библиомир, 2015).

${ }^{3}$ Harry Faulkner-Brown, Some thoughts on the design of major library buildings, http://archive. ifla.org/VII/s20/intlib.1.pdf (acc. 12.03.2018).

${ }^{4}$ Jacek Nowiński, „Działalność i wizerunek instytucji kultury w miastach”, in Kultura miejska $w$ Polsce z perspektywy interdyscyplinarnych badań jakościowych, ed. Wojciech Józef Burszta, Mirosław Duchowski, Barbara Fatyga, Albert Hupa, Piotr Majewski, Jacek Nowiński, Mirosław Pęczak, Elżbieta Anna Sekuła, Tomasz Szlendak (Warszawa: Narodowe Centrum Kultury, 2010), 145-149, 170-172.

${ }^{5}$ Polscy bibliotekarze animatorzy, wychodząc z założenia, iż powodów do czytania jest tyle, ile dobrych książek, promowali biblioteki i czytelnictwo, organizując cykliczną impreze „Noc w Bibliotece”, podczas której wielu czytelników odwiedzało bibliotekę o nietypowej porze. Każda edycja była organizowana pod innym hasłem przewodnim, związanym ze światem książek, np. „W krainie baśni Dalekiego Wschodu”, „Popołudniowe spotkania z polską bajką i legendą”. Coroczne akcje stały się okazją do pokazania wielowymiarowej, wielofunkcyjnej biblioteki, która zapraszała do czytania w niekonwencjonalny sposób, do korzystania z jej ludycznej (zabawowej) funkcji (nocne konkursy, bibliofantoloteryjka itp.). 
jest otwarta, ale obiecuje, że zobaczymy jeszcze coś innego ${ }^{6}$. Na całym świecie przedstawiciele sztuk plastycznych (artyści, performerzy, plastycy amatorzy, architekci, designerzy, projektanci przemysłowi itd.), a także współpracujący z nimi społeczni aktywiści, członkowie lokalnych społeczności oraz obrońcy zachowania książki drukowanej w czasach powszechnego panowania światowych sieci komputerowych, przełamując stereotypy myślenia i działania, proponowali i realizowali eksperymentalne biblioteki alternatywne, usytuowane $\mathrm{w}$ nietypowych przestrzeniach i miejscach. W ich konceptualizacji i realizacji (projekty, indywidualne koncepty, instalacje, akcje i inne) twórcy odwoływali się do różnych tradycji sztuki publicznej, m.in.: community art (,sztuki dialogowej”, „zaangażowanej społecznie”, „sztuki opartej na społeczności”), sztuki partycypacyjnej, zwanej także sztuką wspólnoty (rodzaje współudziału - dydaktyczny, zabawowy itd.). Nietypowe usytuowanie bibliotecznych obiektów w naturalnym krajobrazie, na plażach, w parkach itp. oraz w miejscach publicznej i społecznej przestrzeni współczesnych miast redefiniowały pojęcie biblioteki, zmieniały jej formę i treść, nadawały nowe znaczenia i funkcje. Alternatywne biblioteki miały określony kontekst i program (artystyczny, edukacyjny, społeczny, ekologiczny, interwencyjny), były ukierunkowane na otwartość zdobywania nowych doświadczeń i otwartość na innych. Kierowały się również własnymi regułami: działały na zasadzie akcji i interakcji, w oparciu o proces wymiany, były samoobsługowe i bezpłatne. Uwolnione ze ścian gmachu półki z książkami (stały komponent wewnętrznej bibliotecznej przestrzeni), czy też rozmaite projekty małej architektury o artystycznych walorach, które służyły wypożyczaniu i czytaniu książek w miejscach publicznie dostępnych, przekształcały każdą przestrzeń w inspirujące intelektualnie, znaczące miejsca. Uwzględnienie wszystkich konceptów i artystycznych konkretyzacji bibliotek alternatywnych nie jest możliwe w ramach artykułu, ograniczonego liczbą stron wydawniczych. Odwołując się do paradoksu starożytnego poety i filozofa Empedoklesa (ok. 494-434 p.n.e.), według którego doskonałość dzieł polega na ich „niedoskonałości”, czyli na zawartej w nich przestrzeni dla współtwórczej aktywności tych, którzy się z nimi wciąż spotykają: doskonałe jest to, co można rozwijać i uzupełniać - propozycją badawczą jest analiza wybranych reprezentacji alternatywnych bibliotek (biblioteka w przestrzeni natury; biblioteki na plaży; otwarta publiczna biblioteka jako przykład radykalnej demokracji; biblioteka jako „rzeźba wiedzy”; biblioteki uliczne (idea i praktyka bookcrossingu, małe darmowe biblioteki); biblioteka jako obiekt sztuki współczesnej), oparta na problemowych wyznacznikach interpretacyjnych, podporządkowanych formule „Od natury do kultury”.

${ }^{6}$ Maurice Merleau-Ponty, Fenomenologia percepcji (Phenomenologie de la perception), trans. Małgorzata Kowalska et Jacek Migasiński (Warszawa: Aletheia, 2001). 


\section{Biblioteka w przestrzeni natury}

Amerykański artysta David Harper w Parku Sztuki w Nowym Jorku ze zwalonych drzew i książek stworzył instalację Regały. Zamysłem autora było skonstruowanie funkcjonalnych bibliotecznych mebli prowokujących do myślenia. Dzieło oparte na logice metonimii symbolizowało potęgę twórczości i wiedzy. Regaty ukazywały proces ewolucji od natury do kultury, przemianę żywego drzewa w bibliotekę - miejsce do zdobywania wiedzy. Jeden regał tworzyła kłoda z uschniętego drzewa, która przekształcała się w chwiejącą się półkę, ta z kolei w solidny regał z ułożonymi na nim książkami. Znaczenie relacji między poszczególnymi elementami instalacji kształtował literacko-ekologiczny kontekst. Jej temat - „Te drzewa będą moimi książkami”, Harper zaczerpnął ze sztuki Williama Shakespeare'a Jak wam się podoba. Jednakże sens jego działań wychodził poza ramy pragnień Orlando, by uwiecznić na drzewach w formie wierszy miłość do Rozalindy. Harper chciał uwiecznić w dziele sztuki miłość do wiedzy oraz złożyć hołd żywym tworom natury, które człowiek wykorzystuje dla intelektualnego rozwoju. Instalacja zachęcała do rozszerzania horyzontów myślowych poprzez czytanie, namysłu nad pochodzeniem przedmiotów, przypominała o ochronie przyrody ${ }^{7}$. Autorem niekonwencjonalnej biblioteki, zaaranżowanej w winnicy średniowiecznego opactwa świętego Piotra w Ghent (Belgia), był włoski artysta Massimo Bartolini. Instalacja Plac książek (2012), w której w artystycznym geście zostały połączone dwa wydawałoby się niekompatybilne pojęcia - winnica i biblioteka, wpisywała się w kontekst tradycji narodowej Belgów, dla których uprawa winorośli stanowi integralną część historii, kultury, podmiejskiego krajobrazu, jest turystyczną „wizytówką” kraju. Biblioteka pod gołym niebem promowała czytanie książek na łonie natury. Dwanaście regałów, których zielona barwa harmonizowała $\mathrm{z}$ otoczeniem, a ich usytuowanie i kształt przedłużały linię winorośli, uzasadniało sens działań artystycznych: książki - podobnie jak wino, rozjaśniają umysł. Biblioteka-winnica była publicznie dostępna. Z księgozbioru można było korzystać na zasadzie wymiany lub drobnych datków ${ }^{8}$. Partycypacyjny, społeczno-artystyczny projekt otwartej biblioteki w Parku Levinsky'ego (2009, Tel Awiw) opierał się na myśli izraelskiego prozaika SY Agnona (Samuel/Szmuel Josef Agnon, 1887-1970), który uważał, że gdy świat wypełnia się ciemnością, ludzie powinni czytać książki, by zobaczyć inny świat, oraz założeniu, iż dostęp do książek jest podstawowym prawem człowieka. Efektowny od strony architektonicznej i funkcjonalnej obiekt bez ścian i drzwi,

${ }^{7}$ Oliwia Gissing, The David Harper Stacks Installation is Evolutionary, https://www.trenthunter. com/trends/David-harper-stacks (acc. 10.03.2018).

${ }^{8}$ Leon Kaye, Massimo Bartolini's Bookyard is an Outdoor Library in a Belgian, https:// inhabitat.com/massimo-bartolini's-bookyard-brings-together-a-belgian-vineyard-and-an-outdoorlibrary (acc. 21.02.2018). 
z przezroczystymi, podświetlonymi półkami, składał się z trzech tysięcy książek w szesnastu językach ${ }^{9}$. Był także ciekawą propozycją rozwiązań przestrzennych opartych na kategorii otwartości, która znosiła granice między kulturą (biblioteka) a naturą (park), uczestniczyła w budowaniu relacji międzyludzkich, kulturalnych, społecznych. Biblioteka jako centrum kulturalno-społeczne była miejscem integracji mieszkańców izraelskiej dzielnicy i osób o statusie nielegalnego emigranta. Ciekawie zaaranżowane wnętrze, zapewniające imigrantom bezstresowe korzystanie ze zbiorów, było miejscem fizycznego i psychicznego azylu. Zewnętrzna i wewnętrzna przestrzeń obiektu niosła pozytywne przesłanie: „czytanie książek może zmienić ciebie i twoje otoczenie”. Innowacją biblioteki, interpretowanej jako mały, równoległy świat, w którym książki wędrują między półkami, jak ich czytelnicy po świecie, niosąc ze sobą emocjonalną historię, był unikalny system indeksujący i katalogujący reakcje emocjonalne czytelników po lekturze. System zmieniał układ księgozbioru, tworzył mape przemieszczania się książek, która pokazywała aktualny stan opinii i preferencji czytelników, odzwierciedlała ducha biblioteki oraz losy jej użytkowników ${ }^{10}$.

\section{Biblioteki na plaży}

W wielu miastach świata rozpowszechnił się trend organizowania sezonowych bibliotek na pobliskich plażach. Namiastka kultury promująca czytelnictwo w miejscu, w którym zazwyczaj dominują aktywne, hałaśliwe formy rozrywki, poza wymiarem edukacyjnym i relaksacyjnym, często była ciekawą realizacją o walorach estetycznych. Nie odbiegając od stylistyki plażowej, improwizowane biblioteki na piasku miały rozmaity kształt, design i kolorystykę. Plenerowe czytelnie działały na zasadzie akcji i interakcji, były samoobsługowe i bezpłatne, oferowały formę wypoczynku, który łączył wysiłek intelektualny i fizyczną bierność.

Jedna z pierwszych bibliotek, zaaranżowana $\mathrm{w}$ przyczepie pomalowanej w rozmaite wzory w jaskrawych barwach, powstała w portowym mieście IJmuiden w Holandii. W ten sposób lokalne władze wdrażały projekt walki z wszechpanującymi czytelniami elektronicznymi. Dużą plażową bibliotekę w Bułgarii (projekt niemieckiego architekta Hermana Kompernasa) uruchomiono w turystycznej miejscowości Albena, której nazwa pochodzi od imienia tytułowej bohaterki sztuki (1930) Jordana Jowkowa (1880-1937). Na ustawionych w półkole

\footnotetext{
${ }^{9} \mathrm{~W}$ bibliotece znajdowały się książki w języku: mandaryńskim, tigrickim, amharskim, tajskim (syjamskim), tagalog, arabskim, hebrajskim, francuskim, hiszpańskim, nepalskim, bengalskim, hinduskim, tureckim, rumuńskim, rosyjskim, angielskim.

${ }^{10} \mathrm{~W}$ Izraelu, w którym uchodźcom i pracownikom migrującym nie przyznano pełnych praw, innowacyjny system katalogowania był gestem symbolicznym, który włączał ich jednostkowe interpretacje w kreowanie ogólnodostępnych bibliotecznych zbiorów.
} 
białych regałach do dyspozycji turystów oddano tysiące książek w kilkunastu językach, m.in. bułgarskim, rosyjskim, angielskim, niemieckim. Celem działań było rozpowszechnienie czytania, które sprzyja międzykulturowej komunikacji. Dostęp do książek, które uporządkowano według krajów, z których pochodziły, był swobodny. Ważną rolę odegrały: wizualny aspekt obiektu, darmowy dostęp do publikacji oraz zasada międzykulturowej wymiany jako sposób wchodzenia w przestrzeń drugiej kultury ${ }^{11}$. Ciekawą formę mobilnej biblioteki w indywidualnym stylu zaprezentowała na plaży Romaniquette (Istres, Francja) projektantka przemysłowa Matali Crasset. Podstawę księgozbioru stanowiły jej ulubione książki: powieść Georges'a Pereca Rzeczy. Historia z lat sześćdziesiątych (1965), Poetyka przestrzeni (1957) Gastona Bachelarda, Wszystko dla pań (1883) Emila Zoli, Duma i uprzedzenie (1813) Jane Austen, nowela Zjedzcie mnie (2006) Agnès Desarthe. Do korzystania z literatury zachęcała wizualnie dyskretna forma zewnętrzna (w zacienionych dużymi markizami miejscach można było zagłębić się w lekturze) i niebanalnie urządzone wnętrze (książki były częściowo chronione przed wzrokiem czytelników i jednocześnie przykuwały ich uwagę). Plażowa biblioteka w prosty sposób rozbudzała zainteresowania czytelnicze, pozwalała czerpać przyjemność z lektury. Równocześnie odzwierciedlała osobowość Crasset, ukształtowaną czytaniem odpowiednio dobranej literatury, zmieniającej jej miłośników w tych, którymi ostatecznie się stają. Zatem, parafrazując myśl filozofa Gilles'a Deleuze'a: by poznać kogoś, warto zapoznać się z jego biblioteką.

Projekty alternatywnej biblioteki, stawiając pytanie o nowe miejsca dla niej, poruszały temat specyfiki przestrzeni miejskiej. Było to widoczne w instalacjach amerykańskiego artysty-performera Malika Shaheryara. W autorskim projekcie Czytanie, który był dziełem sztuki i procesem wymiany, artysta proponował redefinicję prezentacji opatrzonych przedstawień miejsc w Nowym Jorku „wrzucanych" w postaci fotografii autoportretowej (ang. selfie) do Internetu. W zaludnionych przestrzeniach (Central Park, Broadway, Most Brookliński) lub miejscach mniej atrakcyjnych, Shaheryar ustawiał stosy z przeczytanych książek ze swojej prywatnej biblioteki. Do niekonwencjonalnych konstrukcji dołączał instrukcję: „Weź książkę, przeczytaj ją i podziel się swoimi myślami z artystą drogą elektroniczną". Wymiana realnego przedmiotu na myśli i emocje, odwołujące się do określonego systemu wartości, tożsamości, ,ja” artysty i potencjalnych czytelników, komplikowała prostą z założenia sytuację. Wybór książek, odzwierciedlających szeroki krąg czytelniczych zainteresowań performera, przeniesienie ich z prywatnej przestrzeni w publiczną tworzyły nowe konteksty i znaczenia. Dla Shaheryara był to sposób, by podzielić się swoim czytelniczym

${ }^{11}$ Albena's Ingenious Beach Library - Travel Away, https://travelaway.me/beach-library-albena/ (acc. 5.03.2018). 
doświadczeniem z miastem, które rzadko zatrzymuje się, by wziąć udział w realnym świecie komunikacji. Niekonwencjonalna biblioteka uświadamiała, iż wchodzenie w kontakt $\mathrm{z}$ realną rzeczywistością daje większą szansę na relacje z innymi niż rzeczywistość wirtualna ${ }^{12}$.

\section{Otwarta publiczna biblioteka jako przykład radykalnej demokracji}

Współpracujący ze sobą artyści fotograficy - pochodzący z Dublina Michael Clegg i urodzony w Jerozolimie Yair Martin Guttmann - jeszcze pod koniec XX wieku urzeczywistnili w przestrzeniach publicznych projekty biblioteki, których warunkiem realizacji i decydującym kryterium był aktywny udział lokalnej społeczności. Model otwartej publicznej biblioteki (1987) polegał na tym, że artyści stawiali półki z książkami w różnych punktach stanu New Jersey ${ }^{13}$. Podstawę teoretyczną projektów odwołujących się do sfery sztuki stanowiło specyficzne odczytanie Teorii awangardy (1974) Petera Bürgera. Artyści przyjęli opisany przez niego zamysł awangardy historycznej połączenia sztuki z praktyką życiową, ale zignorowali historyzację tego zamierzenia ${ }^{14}$. Projekty odwoływały się także do idei „społecznej rzeźby” w rozumieniu niemieckiego artysty, teoretyka sztuki Josepha Beuysa (1921-1986), której intensywność i konkretny kierunek konstytuuje określone dzieło, dodając mu tę lub inną funkcję. W opublikowanym w czasopiśmie „Durch” tekście Plan biblioteki pod otwartym niebem (1990), Clegg i Guttmann sformułowali podstawowe idee swojej koncepcji: „Biblioteka bez bibliotekarzy i nadzoru, której zbiór tworzony jest przy pomocy systemu wymiany przez samych czytelników, zgodnie z którą każdą wziętą książkę powinna zmienić inna. Biblioteka jako instytucja tego typu mogłaby przyczyniać się do samookreślenia się społeczności stając się jej portretem"15. Projekty charakteryzował wysoki stopień konceptualizacji i staranność w ich wykonaniu. Ich celem było zawieszenie podstawowych właściwości instytucji biblioteki społecznej. Otwarta biblioteka (1991, Graz, Austria) - trzy rozmieszczone w przestrzeni miasta niezabezpieczone regały z książkami, które można było brać bez nadzoru, ograniczeń i komplikacji administracyjnych, ujawniła komunikatywne

${ }^{12}$ Tajemnicze stosy ksiażek $w$ Nowym Jorku, czyli jak pewien artysta podzielit się z obcymi ludźmi swoją biblioteczka, http://booklips.pl/newsy/tajemnicze-stosy-ksiazek-w-nowym-jorku-czylijak-pewien-artysta-podzielil-sie-z-obcymi-ludzmi-swoja-biblioteczka/ (acc. 29.03.2018).

${ }^{13}$ Półki, które były usytuowane w mało zaludnionych miejscach, np. na cmentarzu żydowskim w Krems, miały surrealistyczny charakter i robiły na odbiorcach duże wrażenie.

${ }^{14}$ Seria Otwarta biblioteka wskazywała na możliwość częściowej reorganizacji żądań awangardy historycznej, np. „zniesienia przeciwieństwa między twórcą a odbiorcą”. Peter Bürger, Theorie der Avantgarde (Frankfurt/Main: Suhrkamp, 1981), 72.

${ }^{15}$ Claus Friede, „Interview mit Clegg \& Guttmann”, in Clegg \& Guttmann, Die Offene Bibliothek, ed. by Achim Könneke (Hamburg/Ostfildern: Cantz, 1994), 18. 
możliwości instalacji, umocniła międzyludzką solidarność bazującą na wymianie książek. Otwarta biblioteka (1993, Hamburg) była bardziej dojrzałą realizacją. W trzech demograficznie zróżnicowanych dzielnicach artyści przekształcili w ogólnodostępne biblioteki rozdzielnice elektryczne, które zaopatrzyli w półki i szklane drzwi. Książki ofiarowali rezydenci dzielnic. Przed biblioteką znajdowała się jedna zasada korzystania z niej: „Proszę, bierzcie książki do wyboru i zwracajcie je po upływie rozsądnego czasu. Uzupełnienie zbioru jest mile widziane". Brak dalszych wskazówek i instancji nadzoru przenosiło odpowiedzialność za funkcjonowanie i los biblioteki na jej użytkowników. Stopień udziału mieszkańców w projekcie był zróżnicowany. Jednakże sytuacje komunikacyjne i ukształtowane w czasie eksperymentu społeczne współzależności wskazywały, iż tego typu demokratyczna forma korzystania z książek jest potrzebna.

\section{Biblioteka jako „rzeźba wiedzy”}

Clegg i Guttmann byli także autorami bibliotek, tzw. „rzeźb wiedzy”, które konstruowali w wewnętrznej i zewnętrznej przestrzeni. Biblioteki funkcjonowały w formie konceptualnie konstruowanych półek na książki, jako portret grupowy lub symbol pamięci zbiorowej. Instalacja Fatszywa perspektywa (2001) zmieniała postrzeganie przestrzeni za pomocą szeregu urządzeń inspirowanych zasadami iluzji perspektywy. Seria trójwymiarowych trompe l'oeil półek z książkami różnych dziedzin: geometrii, architektury, psychologii, lingwistyki, teorii politycznej, religii odtwarzała sekcje regałów z bibliotek w Mediolanie, Nowym Jorku i Berlinie. Optyczny efekt powiększania przestrzeni tworzyły regały skonstruowane na zasadzie projektowania sceny teatralnej. Termin „rzeźba wiedzy”, nadany przez artystów półce z książkami, ilustrował różnicę między widzialną rzeczywistością a tym, co jest pod nią ukryte. Alegoryczne znaczenie biblioteki jako miejsca pamięci było tematem instalacji Sha'at'nez. Wysiedlona/przeniesiona biblioteka (2004, Wiedeń). Kolaż z różnych półek dawał tymczasowe schronienie rozproszonemu księgozbiorowi Sigmunda Freuda. Artystów interesowało fizyczne przeniesienie książek i freudowskie pojęcie zastąpienia lub substytucji. Główną ideą projektu był ustawiony w sklepie koło Muzeum Freuda tymczasowy Aneks do biblioteki, który składał się z kolekcji książek o tematyce przemieszczenia, w znaczeniu psychoanalitycznym tego terminu. W zamyśle artystów miał to być przewodnik po projektowaniu regałów bibliotecznych, metodach selekcji książek, zasadach korzystania z księgozbioru. Aneks został zaprojektowany jako przestrzeń przemieszczenia i repozytorium (miejsce przechowywania). Była to rzeźba społeczna, która odzwierciedlała instytucjonalne aranżacje budowli, konstrukcje intelektualne i stosunki społeczne. W myśl zasady, iż biblioteka, jako jeden z przejawów demokracji, powinna być zorientowana na użytkownika jej zasobów 
oraz na spacerującego po mieście mieszkańca, instalacja została zaprojektowana dla odbiorców wewnętrznych (czytelnicy) i zewnętrznych (przechodnie), którzy pozostawali względem siebie w relacji przesunięcia. Podział uczestników miał wywołać refleksję na temat przesiedleń i związanych z nimi problemów, a także zwrócić uwagę na różnice między przedmiotami i instytucjami, obserwacją i doświadczeniem, perspektywami wewnętrznymi i zewnętrznymi. Sha'at'nez to termin biblijny (Księga Kapłańska 19:19), który oznacza kombinacje pozbawione organicznej jedności, będącej wynikiem połączenia obcych sobie rzeczy. Wyparte z kontekstu oryginału elementy sha'at'nez (wszyscy wysiedleni), które same $\mathrm{w}$ sobie były formą przemieszczenia, zostały wkomponowane w nową heterogeniczną strukturę. Zbiór książek o tematyce związanej z przesiedleniem został skompletowany z reprodukowanych fragmentów bibliotek: replik półek oryginalnej biblioteki Freuda, jego Muzeum w Londynie, Instytutu Psychiatrycznego w Nowym Jorku i regałów z mieszkania. Książki zostały podzielone na oryginalne wydania z kolekcji psychoanalityka, ich faksymile, atrapy i inne książki. Los Freuda jako „osoby wysiedlonej” został upamiętniony w postaci hybrydowej krzywej wieży tymczasowo łączącej jego rozproszoną kolekcję. Podzielona na regały Biblioteka Moebiusa (2005) odwoływała się do dwuwymiarowej struktury typologii Jacques'a Lacana, w której nie ma rozróżnienia między górą i dołem, wewnętrznym i zewnętrznym. Instalacja komentowała arbitralność aktu zbierania i porządkowania książek. Podążanie za krzywą powodowało powrót do tego samego punktu, ale w przeciwnym kierunku. Biblioteka piramida (2007) nawiązywała do modelu włoskiego studiolo epoki renesansu - małego pokoju poświęconego czytaniu, studiowaniu i pisaniu. Konstruktywnym narzędziem modelowania percepcji eksperymentalnych realizacji Clegga i Guttmanna była otwartośćc ${ }^{16}$.

\section{Biblioteki uliczne}

Inną narracją i formą działania posługiwali się twórcy, którzy na potrzeby alternatywnej biblioteki adaptowali i przekształcali funkcjonujące w przestrzeni miast obiekty (budki i automaty telefoniczne, przystanki komunikacji miejskiej, środki transportu itp.) lub, odwołując się do znanego sądu malarza i rzeźbiarza Marcela Duchampa (1887-1968), że „wszystko jest sztuką”, przenosili z prywatnej przestrzeni w przestrzeń publiczną przedmioty użytkowe (telewizory, lodówki itp.). Inni pomysłodawcy tworzyli nowe miejsca i obiekty (szafy, półki, gabloty, stoliki, ławki, transformery, gogol-moduły ${ }^{17}$ ). Reakcje odbiorców na podejmowane

${ }^{16}$ Materiał został opracowany na podstawie wielu źródeł pochodzących z Internetu.

${ }^{17}$ Gogol-moduł - transformer w kształcie tunelu wyposażony w półki na książki, ławki, stolik. Jego nazwa pochodzi od nazwiska rosyjskiego pisarza Nikołaja Gogola (1809-1852). Jest to rodzaj małej biblioteki, czytelni, który od 2012 roku funkcjonuje w moskiewskich parkach. 
działania w większości były pozytywne, miały charakter interaktywny lub partycypacyjny. Na całym świecie rozpowszechniła się idea bookcrossingu (wymiana książek, książko-krążenie, książka w podróży) czy też book sparingu (dzielenie się), którą w 2001 roku zaproponował amerykański specjalista od technologii Internetu Ron Hornbaker. W narracjach działań bookcrossingowych wyraźnie zaznaczyła się problematyka odwołująca się do samej książki, problemu czytania oraz niekonwencjonalnego sposobu ich popularyzowania. Bookcrossing jako idea i praktyka nieodpłatnego przekazywania książek przez pozostawianie ich w miejscach publicznych (często nietypowych: na ławkach, schodach, na murkach, pod drzewem, niekiedy artystycznie opakowanych) lub specjalnie do tego celu stworzonych, w taki sposób, by inni je znaleźli, przeczytali i postąpili podobnie, pozwalała poszerzyć granice czytania i poszukiwania informacji, upowszechnić czytanie, zjednoczyć czytelników różnych narodowości, w różnym wieku, o odmiennych upodobaniach czytelniczych. Bookcrossing jako nowy kreatywny ruch społeczny zwracał książce jej odwieczny sens, wartość samą w sobie, którą posiadała od czasów Gutenberga. Uliczna biblioteka stała się także ciekawym elementem miejskiego designu. Innowacyjną formą była próba powiązania literatury ze sztuką. Projekt małej, darmowej biblioteki (Little Free Library), który powstał w USA, rozpowszechnił się na całym świecie. Małe biblioteki cieszyły się powodzeniem w Niemczech, Austrii, Szwajcarii. Coraz więcej zwolenników zyskiwały także w Polsce. Mimo wariantowości form i wzornictwa, wszystkie obiekty funkcjonowały na zasadzie bookcrossingu. Na jednej z ulic Berlina designerzy wykonali bezpłatną wypożyczalnię Las ksiażek z pni drzew, które tworzyły klaster drzewny. Umieścili w nim półki z książkami i ochronili małymi oknami. Biblioteka funkcjonowała $\mathrm{w}$ kontekście ekologicznym (przerabianie drewna na papier, następnie na książkę) i edukacyjnym (zachęcanie do czytania poza murami biblioteki instytucjonalnej). W Tarnowie w ramach projektu „Mobilne biblioteczki” powstała półka bookcrossingowa $W$ głowie się zmieści, pótkowe myśli (2017) autorstwa lokalnego plastyka Jacka Adamczyka. Ludzka głowa wypełniona książkami została zainspirowana postacią tarnowskiego wynalazcy Jana Szczepanika (1872-1926) zwanego „polskim (austriackim) Edisonem”, „Leonardem da Vinci z Galicji”. W Ostrowcu Świętokrzyskim powstała minibiblioteka społeczna Książodzielnia (2014). Jej oryginalna nazwa, składająca się ze słów „książka”, „dzielić się” i „dzielnia” (w slangu młodzieżowym - dzielnica, ulica, na której się mieszka) odzwierciedlała istotę i funkcje obiektu. Na bocznej ściance znajdował się cytat Wisławy Szymborskiej - „Czytanie książek to najpiękniejsza zabawa, jaką sobie ludzkość wymyśliła”" ${ }^{18}$. Na zabawie i nauce

${ }^{18}$ Kamil Stelmasik, Barbara Maria Morawiec, Ksiażkodzielnia - czyli jak dzielić się ksiażkami $z$ innymi, http://lustrobiblioteki.pl/2017/07/ksiazkodzielnia-czyli-jak-dzielic-sie-ksiazkami-z-innymi/ (acc. 29.03.2018). 
opierały się działania kreatywnej młodzieży w Oświęcimiu, która w ramach projektu „Nieruchomość Literacka” w różnych punktach miasta ustawiła ciekawe obiekty małej architektury z wykreowanymi indywidualną wyobraźnią postaciami Mikołajka, Małego Księcia, Harry’ego Pottera, Kubusia Puchatka, Koziołka Matołka i innych.

\section{Biblioteka jako obiekt sztuki współczesnej}

$\mathrm{Na}$ przestrzeni wieków literatura była podstawą rozwoju kultury, nauki i społeczeństwa. W świecie funkcjonowania cyfrowych technologii drukowanym książkom coraz trudniej znaleźć swoje miejsce, pełnić wyznaczoną od wieków rolę. Niepotrzebne, zużyte wydania podlegają utylizacji, są palone, przeznaczane na makulaturę. Aby przedłużyć egzystencję książek w przestrzeni publicznej (otwartej - street art, murale lub zamkniętej), twórcy całego świata podejmowali rozmaite działania, w których zmieniali je $\mathrm{w}$ obiekt sztuki ${ }^{19}$. W tej roli książki często wracały w obręb zamkniętej ścianami przestrzeni instytucjonalnej (galerii, muzeów) lub same je konstruowały jako nietypowy budulec. Przechodząc ze sfery werbalnej w sferę wizualną, książka traciła część swoich funkcji (nie można było jej otworzyć, przeczytać, dotknąć), stawała się obiektem do oglądania, ilustracją czyjejś wyobraźni, płótnem dla artysty, odbiciem jego kunsztu artystycznego. W przestrzeni sztuki drukowana książka funkcjonowała jako alegoria w benjaminowskim duchu, którą autor Pasaży rozumiał jako element wyrwany ze swojego życiowego kontekstu, pozbawiony swoich pierwotnych funkcji, następnie umieszczony w sąsiedztwie innych fragmentów nadających mu zupełnie nowy i niezależny sens. Kalifornijski artysta Mike Stylki od lat tworzy biblioteki-wystawy, zmieniając spisane na straty stare tomy w rysunki melancholijnych, fikcyjnych postaci, zwierząt oraz portrety znanych osób, np. Henry'ego Charlesa Bukowskiego (1920-1994) - amerykańskiego poety, powieściopisarza, rysownika. Miler Lagos z Kolumbii, apelując do zachowania równowagi między naturą a kulturą, w pustej przestrzeni galerii zainscenizował instalację Dom $(2011)^{20}$. Z wybranych książek nieistniejącej już biblioteki US Navy artysta, kładąc warstwa po warstwie obcojęzyczne słowniki, medyczne i geograficzne serie, tomy psychologii (jak Inuici lodowe bryły), wyrzeźbił igloo. Dom rdzennych mieszkańców obszarów arktycznych Lagos interpretował jako miejsce, w którym (jak w bibliotece)

\footnotetext{
${ }^{19}$ Grażyna Bobilewicz, „«Книга художника» как интермедиальный дискурс”, Poznańskie Studia Slawistyczne. Intersemiotyczność, no. 2 (2012): 41-69; Grażyna Bobilewicz, „Гибридные коды и формы боок-арта", in Губридные формы в славянских культурах (Москва: Институт славяноведения РАН, 2014), 368-389.

${ }^{20}$ Konstruowanie obiektów architektonicznych z książek to popularny trend w światowej sztuce współczesnej.
} 
przechowuje się, odtwarza, przekazuje z pokolenia na pokolenie nagromadzoną wiedzę. Igloo-biblioteka to także symbol przestrzeni bezpieczeństwa. Dom chroni Inuitów przed nieokiełznaną naturą jak biblioteka książki przed zniszczeniem $^{21}$. W instalacji Książki (2015) grupy rosyjskich artystów „Przerębel” zamknięta przestrzeń ścian zbudowanych $\mathrm{z}$ woluminów wpisywała się w ramy interpretacyjne tradycyjnej biblioteki rozumianej jako fundament społeczeństwa. Między tradycją a współczesnością oscylowała postać bibliotekarza. Jego zachowanie (siedział przy biurku wpatrzony w notebook) ucieleśniało pozycję nowoczesnego człowieka w odniesieniu do kultury, który szuka oparcia w tradycji i równocześnie korzysta z nowoczesnych nośników informacji.

Ideę otwartych ulicznych bibliotek popularyzowały różnorodne akcje partycypacyjne. Spektakularną instalację „Tonący książki się chwyta” (2016) zainscenizowały na Moście Uniwersyteckim we Wrocławiu artystki Joanna Grzelczyk i Małgorzata Grączewska. Pretekstem do snucia narracji było ratowanie zbiorów Biblioteki Uniwersyteckiej podczas powodzi w 1997 roku oraz uniwersalna wartość książki. Przekształcona we wspólnotowe działanie artystyczne akcja społeczna sprzed lat funkcjonowała w sposób dosłowny (wysiłek codzienności) i przenośny (narracja o książce jako o ratunku i wybawieniu), akcentowała zaangażowanie społeczne (woluminy ofiarowywali uczestnicy) i interakcję odbiorców. Przechodząc z rąk do rąk, książki stały się budulcem monumentalnej rzeźby (wału przeciwpowodziowego) - swoistego rodzaju biblioteki pod odkrytym niebem, której zbiory były dostępne dla wszystkich ${ }^{22}$. Z inicjatywy argentyńskiej artystki konceptualnej - Marty Minujin, na placu San Martin w Buenos Aires (2011) stanęła dwudziestopięciometrowa współczesna Wieża Babel. Instalacja zrealizowana w ramach autorskiego projektu Ksiązki Wieży Babel została skonstruowana z dziesiątków tysięcy woluminów wszystkich gatunków i dziedzin z ponad pięćdziesięciu krajów świata (w tym z Polski) ${ }^{23}$. Zgodnie z artystyczną koncepcją Nowy Babilon, spiralna galaktyka książki ucieleśniały model jednej światowej, wielojęzycznej kultury, której wiedza (symbol jej bogactwa) łączy narody, sprzyja międzykulturowemu dialogowi. Partycypacyjne działanie odsyłało do licznych kontekstów tytułowego symbolu (interpretacje Jacques'a Derridy, Rolanda Barthes'a) i wywoływało literackie skojarzenia. Instalacja była wyrazem hołdu dla kreatywnej wyobraźni argentyńskiego pisarza Jorge Luisa Borgesa, wizualną aluzją do jego opowiadania Biblioteka Babel (1944). Wykreowana moca pisarskiej wyobraźni biblioteka na podobieństwo wszechświata z niekończącym się

\footnotetext{
${ }^{21}$ Miler Lagos, Home, http://www.magnanmetz.com/exhibitions/miler-lagos-home (acc. 26.03.2018).

${ }^{22}$ Joanna Grzelczyk, Małgorzata Grączewska, Tonący książki się chwyta, http://www.wroclaw 2016.pl/tonacy-ksiazki-sie-chwyta (acc. 28.03.2018).

${ }^{23}$ Po rozebraniu instalacji książki Wieży Babel miały stać się fundamentem powstającej w Buenos Aires wielojęzycznej biblioteki.
} 
księgozbiorem, różniła się od realnych bibliotecznych przestrzeni, gdzie Borges pracował, twórczo i przyjemnie spędzał czas.

Niezależnie od formy, treści i funkcji biblioteka zawsze i wszędzie odgrywała ważną rolę w kulturze i społeczeństwie danego kraju. Była także nieustannie przekształcana, podążając za zmianami w czasie i przestrzeni. Przykładem są niekonwencjonalne w zamyśle i wykonaniu, zróżnicowane pod względem konceptualnym, wizualnym i interpretacyjnym, alternatywne biblioteki. Ich wygląd, przestrzeń i miejsca usytuowania indywidualizowały m.in. zastosowane materiały, oryginalne rozwiązania $\mathrm{w}$ zakresie form architektonicznych i przekształceń krajobrazu, kolorystyka, oświetlenie, uniwersalna i lokalna metaforyka, symbolika, sensy naddane itd. W dobie technologii cyfrowych, łatwego dostępu do informacji - książki można pobrać na telefon, przeczytać w elektronicznych bibliotekach, a intelektualnie wypocząć w różnych miejscach, alternatywne biblioteki stały się czynnikiem integracji społecznej w miastach, źródłem inspiracji, wyzwalały u rzeczywistych, jak i potencjalnych ich użytkowników, kreatywność.

\section{Bibliografia}

Albena's Ingenious Beach Library - Travel Away, https://travelaway.me/beach-libraryalbena/ (acc. 5.03.2018).

Bobilewicz, Grażyna. „Книга художника” как интермедиальный дискурс. Poznańskie Studia Slawistyczne. Intersemiotyczność, no. 2 (2012): 41-69.

Bobilewicz, Grażyna. „Гибридные коды и формы боок-арта”. In Гибридные формы в славянских культурах. Москва: Институт славяноведения РАН, 2014, 368-389.

Bürger, Peter. Theorie der Avantgarde. Frankfurt/Main: Suhrkamp, 1981.

Gissing, Oliwia. The David Harper Stacks Installation is Evolutionary, https://www. trenthunter.com/trends/David-harper-stacks (acc. 10.03.2018).

Grzelczyk, Joanna, et Małgorzata Grączewska. Tonący ksiązki się chwyta, http://www. wroclaw2016.pl/tonacy-ksiazki-sie-chwyta (acc. 28.03.2018).

Faulkner-Brown, Harry. Some thoughts on the design of major library buildings, http:// archive.ifla.org/VII/s20/intlib.1.pdf (acc. 12.03.2018).

Friede, Claus. „Interview mit Clegg \& Guttmann”. In Clegg \& Guttmann, Die Offene Bibliothek, ed. Achim Könneke. Hamburg/Ostfildern: Cantz, 1994.

Kaye, Leon. Massimo Bartolini's Bookyard is an Outdoor Library in a Belgian, https:// inhabitat.com/massimo-bartolini's-bookyard-brings-together-a-belgian-vineyard-andan-outdoor-library (acc. 21.02.2018).

Kruszewski, Tomasz. Przestrzenie biblioteki. O symbolicznej, fizycznej i społecznej obecności instytucji. Toruń: Wydawnictwo Naukowe Uniwersytetu Mikołaja Kopernika, 2012.

Lagos, Miler. Home, http://www.magnanmetz.com/exhibitions/miler-lagos-home (acc. 26.03.2018). 
Levinski Garden Library, Tel Aviv, Izrael. A place with no boundries, http://www.world architecturenews.com/project/2011/16730/yoav-meiri-architects/levinski-garden-libraryin-tel-aviv.html (acc. 10.03.2018).

Merleau-Ponty, Maurice. Fenomenologia percepcji (Phenomenologie de la perception), trans. Małgorzata Kowalska et Jacek Migasiński. Warszawa: Aletheia, 2001.

Nowiński, Jacek. „Działalność i wizerunek instytucji kultury w miastach”. In Kultura miejska $w$ Polsce z perspektywy interdyscyplinarnych badań jakościowych, ed. Wojciech Józef Burszta et al. Warszawa: Narodowe Centrum Kultury, 2010, 145-149, 170-172.

Stelmaski, Kamil, et Barbara Maria Morawic. Książkodzielnia - czyli jak dzielić się książkami z innymi, http://lustrobiblioteki.pl/2017/07/ksiazkodzielnia-czyli-jak-dzielic-sieksiazkami-z-innymi/ (acc. 29.03.2018).

Szczygłowska, Lidia. „Architektura bibliotek”. In Fizyczna przestrzeń biblioteki, ed. Maja Wojciechowska. Gdańsk: Oficyna Wydawnicza Edward Mitek, 2013, 22-39.

Tajemnicze stosy książek w Nowym Jorku, czyli jak pewien artysta podzielit się z obcymi ludźmi swoją biblioteczką, http://booklips.pl/newsy/tajemnicze-stosy-ksiazek-wnowym-jorku-czyli-jak-pewien-artysta-podzielil-sie-z-obcymi-ludzmi-swoja-biblioteczka/ (acc. 29.03.2018).

Дубинина, Ольга. Библиотека в пространстве современного города: Архитектура и дизайн. От прошлого к будущему. Москва: Библиомир, 2014.

Матлина, Слава. Библиотечное пространство: воображаемый образ и реальность. Москва: Библиомир, 2015. 